\title{
PENGARUH STURUKTUR MODAL DAN PROFITABILITAS TERHADAP NILAI PERUSAHAAN DENGAN KEPEMILIKAN MANAJERIAL SEBAGAI VARIABEL MODERASI
}

\author{
Rita Kusumawati ${ }^{1}$, Irham Rosady ${ }^{2}$ \\ Program Studi Manajemen Universitas Muhammadiyah Yogyakarta \\ Yogyakarta, Indonesia \\ kusumawatirita@yahoo.com ${ }^{1}$; irhamrosadysiregar@gmail.com²
}

\begin{abstract}
Abstrak
Penelitian ini bertujuan untuk mengkaji pengaruh struktur permodalan dan profitabilitas perusahaan nilai dengan kepemilikan manajerial sebagai variabel moderasi. Populasi dalam penelitian ini adalah perusahaan manufaktur yang terdaftar di Bursa Efek Indonesia (BEI) dalam periode 2013 hingga 2016. Data yang dikumpulkan oleh metode purposive sampling dan sampling hasil yang diperoleh adalah 96 sampel. Teknik analisis digunakan analisis regresi dikelola (MRA) atau interaksi tes. Hasilnya menunjukkan bahwa ibukota struktur yang diukur dengan DER memiliki nilai positif dan signifikan effecton perusahaan, profitabilitas yang diukur oleh ROA memiliki nilai perusahaan yang positif dan significanton, memiliki struktur permodalan yang dikelola oleh kepemilikan manajerial efek negatif dan signifikan di nilai perusahaan dan profitabilitas yang dikelola oleh manajerial kepemilikan memiliki efek negatif dan signifikan pada nilai perusahaan.
\end{abstract}

Kata kunci: Struktur permodalan, profitabilitas, manajerial kepemilikan, nilai perusahaan

\begin{abstract}
This study aims to examine the influence of capital structure and profitability on firm value with a managerial ownership as a variable moderation. The population in this research is the manufacturing companies listed on the Indonesia Stock Exchange (IDX) in period 2013 up to 2016. Data collected by purposive sampling method and the sampling results obtained are 96 sampel. The analysis technique used Moderated Regression Analysis (MRA) or interaction test. The result show that the capital structure as measured by DER has a positive and significant effecton firm value, profitability as measured by ROA has a positive and significanton firm value, the capital structure which moderated by managerial ownership has a negative and significant effect on firm value and profitability which moderated by managerial ownership has a negative and significant effect on firm value.
\end{abstract}

Keywords : Capital Structure, Profitability, Managerial Ownership, Firms Value

\section{PENDAHULUAN}

Pada dasarnya setiap investor yang menanamkan dananya dengan membeli saham perusahaan berharap akan memperoleh kemakmuran yang maksimal. Kemakmuran pemegang saham tersebut tergambar pada nilai perusahan. Nilai perusahaan merupakan 
Jurnal Manajemen Bisnis, Vol 9. No 2, September 2018, E-ISSN:2622-6308 P-ISSN:2086-8200

Website: http://journal.umy.ac.id/index.php/mb

DOI:10.18196/mb.9259

nilai yang diberikan oleh pelaku pasar saham terhadap kinerja perusahaan (Tarjo, 2005). Nilai perusahaan sangat penting bagi para investor sebagai salah satu acuan untuk melakukan investasi terhadap perusahaan. Nilai perusahaan yang dibentuk melalui indikator nilai pasar saham, dipengaruhi oleh beberapa faktor diantaranya adalah: ukuran perusahaan, tingkat pertumbuhan perusahaan, profitablitas, kebijakan hutang, posisi likuiditas perusahaan, struktur modal dan kepemilikan manajerial(Agnes, 2013); Nilai perusahaan juga dipengaruhi oleh kebijakan dividen dan keputusan investasi (Hermastuti, 2014).

Struktur modal merupakan salah satu faktor yang dapat mempengaruhi nilai perusahaan. Modigliani \& Miller (1963) menjelaskan bahwa dengan mempertimbangkan unsur pajak, penambahan utang dalam proporsi struktur modal perusahaan akan meningkatkan nilai perusahaan. Peningkatan nilai perusahaan ini karena adanya penghematan pajak dari bunga yang dibayarkan dan adanya pengurangan biaya keagenan. Beberapa penelitian yang berkaitan dengan pengaruh struktur modal terhadap nilai perusahaan telah dilakukan sebelumnya dengan hasil yang tidak konsisten. Penelitian yang dilakukan oleh Hermuningsih (2012); Moniaga F. (2013); Pratama \& Wirawati (2016); Agnes (2013); Chaidir (2015); dan Lubis, Sinaga, \& Sasongko (2017). membuktikan bahwa struktur modal memiliki pengaruh positif dan signifikan terhadap nilai perusahaan. Sementara itu penelitian yang dilakukan oleh Dewi \& Wirajaya (2013); Hoque, Hossain \& Hossain (2014); Chun \& Lee, (2017) dan Munandar \& Kusumawati (2017). membuktikan bahwa struktur modal berpengaruh negatif dan signifikan terhadap nilai perusahaan.

Profitabilitas yang dihasilkan juga dapat mempengaruhi nilai perusahaan. Profitabilitas merupakan kemampuan perusahaan menghasilkan keuntungan (profitabilitas) pada tingkat penjualan, aset dan modal saham perusahaan (Hanafi, 2014). Profitabilitas perusahaan merupakan variabel penting yang dipertimbangkan perusahaan ketika akan berinvestasi (Sujoko \& Soebiantoro, 2007). Tingkat profitabilitas yang tinggi menunjukkan perusahaan tersebut memiliki kinerja yang baik dan memiliki prospek di masa mendatang. Investor menangkap itu sebagai sinyal positif dan direspon dengan membeli saham perusahaan tersebut Semakin banyak investor yang berminat membeli saham perusahaan berdampak pada meningkatnya harga saham perusahaan dan nilai perusahaan juga akan meningkat. Sujoko \& Soebiantoro, (2007); Ju Chen \& Yu Chen (2011); Dewi \& Wirajaya (2013); Pratama \& Wirawati (2016); Lubis, Sinaga, \& Sasongko (2017); dan 
Jurnal Manajemen Bisnis, Vol 9. No 2, September 2018, E-ISSN:2622-6308 P-ISSN:2086-8200

Website: http://journal.umy.ac.id/index.php/mb

DOI:10.18196/mb.9259

Nandita \& Kusumawati (2018) dalam penelitiannya membuktikan bahwa profitabilitas berpengaruh positif dan signifikan terhadap nilai perusahaan. Hasil dari penelitian yang berbeda ditunjukkan oleh Chaidir (2015); Moniaga F.(2013), yang dalam penelitiannya menjelaskan bahwa profitabilitas tidak berpengaruh signifikan terhadap nilai perusahaan.

\section{KAJIAN TEORI}

\section{Nilai Perusahaan}

Menurut Husnan (2008), nilai perusahaan merupakan harga yang dibayar oleh calon pembeli apabila perusahaan tersebut terjual. Nilai perusahaan adalah penilaian investor untuk keberhasilan perusahaan dan kinerja perusahaan yang tercermin melalui harga saham dipasar. Nilai perusahaan yang dibentuk melaui indikator harga saham di pasar akan menunjukkan adanya peluang-peluang investasi yang baik. Adanya peluang-peluang investasi tersebut dapat memberikan sinyal positif kepada investor tentang kemakmuran yang akan diperoleh investor maupun prospek perusahaan kedepannya sehingga hal ini dapat meningkatkan nilai perusahaan.

\section{Struktur Modal}

Menurut Riyanto (2001), struktur modal adalah perbandingan atau perimbangan utang jangka panjang dengan modal sendiri. Penentuan struktur modal yang efisien juga mempengaruhi kinerja perusahaan untuk mencapai tujuannya.

Teori MM (Modligiani-Miller) pada tahun 1950-an beranggapan bahwa nilai perusahaan tidak dipengaruhi oleh struktur modal, dengan asumsi pasar modal adalah sempurna, tidak ada pengaruh pajak dan pengaruh kebangkrutan sehingga keputusan pendanaan perusahaan menjadi tidak relevan sebagai bahan pertimbangan investasi, artinya penggunaan atau penambahan utang dan modal sendiri tidak akan memberikan dampak terhadap kemakmuran para pemegang saham. Teori MM tanpa pajak dianggap tidak realistis dan kemudian pada tahun 1963 MM memasukkan faktor pajak ke dalam teorinya. Pajak dibayarkan kepada pemerintah, yang berarti merupakan aliran kas keluar. Hutang bisa digunakan untuk menghemat pajak, karena bunga bisa dipakai sebagai pengurang pajak. Dengan memasukkan unsur pajak, maka penambahan utang akan meningkatkan nilai perusahaan dimana peningkatan nilai tersebut karena adanya penghematan pajak dari bunga yang dibayarkan. 
Jurnal Manajemen Bisnis, Vol 9. No 2, September 2018, E-ISSN:2622-6308 P-ISSN:2086-8200

Website: http://journal.umy.ac.id/index.php/mb

DOI:10.18196/mb.9259

Trade-off theory juga menjelaskan pengambilan kebijakan mengenai struktur modal melibatkan trade off antara risiko dengan tingkat pengembalian. Penambahan utang yang dilakukan perusahaan tentunya akan memperbesar risiko yang akan diperoleh perusahaan tetapi hal ini juga sekaligus memberikan tingkat pengembalian yang juga semakin besar.

Signal atau isyarat merupakan suatu tindakan yang dilakukan oleh manajer perusahaan dan disampaikan ke investor tentang bagaimana manajemen memandang prospek perusahaan. Apabila manajer memandang bahwa perusahaan memiliki prospek yang baik dimasa mendatang, manajer ingin agar harga saham di pasar meningkat, dan manajer dapat melakukan hal tersebut dengan memberikan sinyal kepada investor yaitu dengan menggunakan utang yang lebih besar. Dengan ini, diharapkan investor dapat menangkap sinyal bahwa perusahaan memiliki prospek yang baik di masa yang akan datang.

Hanafi (2014) menjelaskan bahwa dalam pendekatan teori keagenan struktur modal disusun sedemikian rupa untuk mengurangi adanya konfilik antar berbagai kelompok kepentingan.Adapun konflik antara pemegang saham dengan manajer misalnya konsep free-cash flow. Ketika perusahaan tidak melihat lagi keputusan investasi yang menarik, perusahaan akan membagikan free-cash flow tersebut kepada pemegang saham untuk menginvestasikannya sendiri. Tetapi ada kecenderungan dimana sumber daya tersebut ingin dikontrol oleh manajer sendiri. Utang bisa dijadikan sebagai cara untuk mengatasi konflik keagenan tersebut.

\section{Profitabilitas}

Menurut Sartono (2001), profitabilitas didefinisikan sebagai kemampuan perusahaan dalam memperoleh laba dalam hubungannya dengan penjualan, total aktiva maupun modal sendiri. Profitabilitas suatu perusahaan sangat penting bagi investor sebagai salah satu pertimbangan dalam berinvestasi, investor beranggapan perusahaan yang memiliki profitabilitas yang tinggi akan memberikan return yang besar juga.

\section{Kepemilikan Manajerial}

Kepemilikan manajerial adalah persentase kepemilikan saham pada perusahaan oleh pihak manajeman (Adyana Putra I, 2013). Struktur kepemilikan pada perusahaan memiliki dampak yang berbeda tentang bagaimana tindakan manajemen dalam mengambil resiko 
Jurnal Manajemen Bisnis, Vol 9. No 2, September 2018, E-ISSN:2622-6308 P-ISSN:2086-8200

Website: http://journal.umy.ac.id/index.php/mb

DOI:10.18196/mb.9259

(Chun S, 2017). Menurut Darmawati \& Rahayu (2004), inti dari hubungan keagenan ini adalah pemisahan antara pengendalian selaku pihak agent dan kepemilikan selaku pihak principal. Investor mempunyai harapan bahwa kekayaan investor dan kemakmuran investor akan bertambah dengan mendelegasikan wewenang pengelolaan pada manajer tersebut.

\section{HIPOTESIS}

\section{Pengaruh Struktur Modal Terhadap Nilai Perusahaan}

Struktur modal merupakan struktur pendanaan perusahaan yang diperoleh dari jumlah utang dan modal sendiri. Signaling Theory menjelaskan tentang bagaimana seorang manajer perusahaan memandang prospek perusahaan dan memberikan sinyal kepada investor atau pemegang saham. Jika manajer memiliki keyakinan yang cukup bahwa perusahaan mempunyai prospek yang baik, maka manajer dapat menggunakan utang yang lebih besar dalam struktur modal perusahaan, yang nantinya tindakan ini bisa dianggap sebagai sinyal yang terpercaya. Investor diharapkan akan menangkap sinyal positif tersebut sehingga investor akan tertarik dan memiliki minat untuk ikut memiliki dan membeli perusahaan tersebut. Tentunya ini akan meningkatkan harga saham di pasar. Selain itu, dalam teori $M M$ yang menjelaskan bahwa dengan mempertimbangkan pajak serta dalam trade-off theory, nilai perusahaan juga ditentukan oleh struktur modal. Semakin tinggi proporsi utang akan meningkatkan proporsi struktur modal yang akan meningkatkan nilai perusahaan. Penjelasan tersebut didukung oleh penelitian yang dilakukan beberapa peneliti seperti Agnes (2013), Moniaga (2013), Chaidir (2015) dan Pratama \& Wirawati (2016). Hasil penelitian mereka menjelaskan bahwa struktur modal berpengaruh positif dan signifikan terhadap nilai perusahaan. Oleh karena itu dalam penelitian ini, hipotesis yang diajukan adalah:

H1: Struktur modal berpengaruh positif dan signifikan terhadap nilai perusahaan.

\section{Pengaruh Profitabilitas Terhadap Nilai Perusahaan}

Menurut Dewi \& Wirajaya (2013), profitabilitas merupakan kemampuan suatu perusahaan dalam menghasilkan laba selama periode tertentu. Profitabilitas akan meningkatkan nilai perusahaan yang tercermin melalui kenaikan harga saham di pasar. Semakin tinggi tingkat profitabilitas suatu perusahaan menunjukkan kinerja perusahaan tersebut semakin baik dan memberikan sinyal bagi prospek pertumbuhan perusahaan di 
Jurnal Manajemen Bisnis, Vol 9. No 2, September 2018, E-ISSN:2622-6308 P-ISSN:2086-8200

Website: http://journal.umy.ac.id/index.php/mb

DOI:10.18196/mb.9259

masa yang akan datang. Hal ini tentu saja akan menarik minat investor untuk berinvestasi dengan memiliki atau membeli perusahaan tersebut. Semakin banyak investor yang berminat untuk membeli saham perusahaan maka berdampak positif pada meningkatnya harga saham di pasar dan pada akhirnya akan meningkatkan nilai perusahaan. Jadi, semakin besar profitabilitas suatu perusahaan maka semakin besar pula nilai perusahaannya. Dari hasil penelitian yang dilakukan oleh Sujoko \& Soebiantoro, (2007); Ju Chen \& Yu Chen (2011); Dewi \& Wirajaya (2013); Pratama \& Wirawati (2016); Lubis, Sinaga, \& Sasongko (2017); dan Nandita \& Kusumawati (2018) menjelaskan bahwa profitabilitas berpengaruh positif dan signifikan terhadap nilai perusahaan. Maka hipotesis yang diajukan dalam penelitian ini adalah:

H2: Profitabilitas berpengaruh positif dan signifikan terhadap nilai perusahaan.

\section{Pengaruh Struktur Modal Terhadap Nilai Perusahaan dengan Kepemilikan Manajerial sebagai variabel moderasi.}

Kepemilikan saham oleh pihak manajemen merupakan salah satu tindakan yang dapat dilakukan untuk mengatasi konflik keagenan antar berbagai kelompok kepentingan yang ada. Jensen \& Meckling (1976) menyatakan bahwa perusahaan yang memiliki kepemilikan manajerial yang tinggi akan menurunkan biaya keagenan. Dengan adanya kepemilikan manajerial dalam perusahaan, maka manajemen memiliki dua peran sekaligus yaitu sebagai agent dan sebagai principall, sehingga terdapat penyatuan kepentingan antara pemegang saham dengan manajemen. Manajemen akan bekerja sungguh-sungguh menggunakan hutang tersebut untuk meningkatkan kinerja perusahaan agar kemakmuran pemegang saham maksimal.

Berdasarkan uraian tersebut, maka hipotesis yang diajukan dalam penelitian ini adalah:

H3: Struktur modal yang di moderasi kepemilikan manajerial berpengaruh positif dan signifikan terhadap nilai perusahaan.

\section{Pengaruh Profitabilitas Terhadap Nilai Perusahaan dengan Kepemilikan} Manajerial sebagai variabel moderasi

Menurut Rahayu \& Andri (2010), struktur kepemilikan dipercaya dapat mempengaruhi jalannya perusahaan dalam mencapai tujuan suatu perusahaan, yaitu 
Jurnal Manajemen Bisnis, Vol 9. No 2, September 2018, E-ISSN:2622-6308 P-ISSN:2086-8200

Website: http://journal.umy.ac.id/index.php/mb

DOI:10.18196/mb.9259

mencapai keuntungan maksimal, memakmurkan pemegang saham dan memaksimalkan nilai perusahaan. Semakin tinggi kepemilikan manajerial dalam perusahaan diharapkan akan menaikkan nilai perusahaan dimana manajemen akan berusaha semaksimal mungkin terhadap kepentingan para pemegang saham. Hal ini berlaku karena pihak manajemen yang selaku pemegang saham juga akan mendapatkan return yang besar apabila perusahaan juga mendapatkan keuntungan yang lebih besar. Ketika perusahaan memperoleh laba yang besar akan memberikan sinyal positif kepada investor dan investor akan berminat untuk memiliki perusahaan yang juga akan mempengaruhi harga saham di pasar. Dari hasil penelitian Anindyati (2011) yang juga didukung penelitian Putra dan Wirawati (2013) menjelaskan bahwa kinerja keuangan yang diproxy ROA berpengaruh positif dan signifikan terhadap nilai perusahaan dengan kepemilikan manajerial sebagai variabel moderating. Maka hipotesis yang diajukan dalam penelitian ini adalah:

H4: Profitabilitas yang di moderasi kepemilikan manajerial berpengaruh positif dan signifikan terhadap nilai perusahaan.

\section{METODE PENELITIAN}

Objek dalam penelitian ini adalah perusahaan manufaktur yang terdaftar di Bursa Efek Indonesia (BEI) pada periode 2013-2015. Sampel diseleksi melalui metode purposive sampling, berdasarkan beberapa kriteria yang ada diperoleh sampel sebanyak 96 sampel. Data dikumpulkan dengan metode dokumentasi yang sumbernya dari website Bursa Efek Indonesia (BEI) wwww.idx.co.id

\section{DEFENISI OPERASIONAL}

\section{Nilai Perusahaan}

Nilai perusahaan merupakan tingkat kinerja dan keberhasilan perusahaan yang tercermin melalui indikator harga saham di pasar. Nilai perusahaan dapat dilihat dengan menghitung Price to Book Value (PBV). (Pratama \& Wirawati, 2016), PBV merupakan nilai pasar saham atas nilai bukunya. Rumus PBV adalah :

$$
P B V=\frac{\text { HargaPasarperLembarSaham }}{\text { NilaiBukuperLembarSaham }}
$$


Jurnal Manajemen Bisnis, Vol 9. No 2, September 2018, E-ISSN:2622-6308 P-ISSN:2086-8200

Website: http://journal.umy.ac.id/index.php/mb

DOI:10.18196/mb.9259

\section{Struktur Modal}

Struktur Modal adalah jumlah perimbangan antara hutang dengan modal sendiri. Struktur modal dapat diukur menggunakan rasio keuangan yaitu rasio utang (debt ratio) dengan mengukur besarnya utang dalam struktur modal terhadap modal sendiri. Struktur modal dalam penelitian ini diukur dengan Debt to Equity Ratio (DER) dengan rumus sebagai berikut (Pratama dan Wirawati, 2016):

$$
D E R=\frac{\text { TotalUtang }}{\text { TotalEkuitas }}
$$

\section{Profitabilitas}

Profitabilitas merupakan kemampuan perusahaan dalam menghasilkan laba dari kegiatan yang dilakukan selama periode tertentu.

Profitabilitas dapat diukur dengan rasio Return On Asset (ROA). Rasio ini mengukur sejauh mana kemampuan perusahaan dalam menghasilkan laba bersih berdasarkan tingkat asset yang dimiliki. ROA dalam penelitian ini dirumuskan sebagai berikut (Hanafi \& Halim, 2012).

$$
R O A=\frac{\text { LabaBersih }}{\text { TotalAset }}
$$

\section{Kepemilikan Manajerial}

Kepemilikan manajerial adalah jumlah kepemilikan saham oleh pihak manajemen berdasarkan seluruh modal saham perusahaan yang dikelola (Agnes, 2103). Kepemilikan Manajerial dalam penelitian ini diukur dengan managerial ownership (MOWN) (Pratama \& Wirawati, 2016). Rumus MOWN adalah sebagai berikut:

$$
\text { MOWN }=\frac{\text { TotalSahamManajerdanDewanDireksi }}{\text { TotalSahamYangBeredar }} X 100 \%
$$

\section{TEKNIK ANALISIS DATA}

Penelitian ini menggunakan moderated regression analysis (MRA) untuk menganalisis interaksi (perkalian dua atau lebih variabel) atau pengaruh dari variabel pemoderasi (Ghozali, 2011).Sebelumnya, telah dilakukan uji asumsi klasik terlebih dahulu yang meliputi 
Jurnal Manajemen Bisnis, Vol 9. No 2, September 2018, E-ISSN:2622-6308 P-ISSN:2086-8200

Website: http://journal.umy.ac.id/index.php/mb

DOI:10.18196/mb.9259

uji normalitas, uji multikolinieritas, uji heterokedastisitas dan ujiautokorelasi. Adapun persamaan regresinya adalah sebagai berikut:

$$
\begin{aligned}
& \mathrm{PBV}=a+\beta 1 \mathrm{DER}+\beta 2 \mathrm{ROA}+\mathrm{e} \\
& \mathrm{PBV}=\alpha+\beta 1 \mathrm{DER}+\beta 2 \mathrm{MOWN}+\beta 3 \mathrm{DER}^{*} \mathrm{MOWN}+\mathrm{e} \\
& \mathrm{PBV}=a+\beta 1 \mathrm{ROA}+\mathrm{b} 2 \mathrm{MOWN}+\beta 3 \mathrm{ROA}^{*} \mathrm{MOWN}+\mathrm{e}
\end{aligned}
$$

Keterangan:

PBV = Nilai Perusahaan; $\alpha=$ Konstanta $\beta=$ Koefisien

DER = Struktur Modal; $\quad$ ROA = Profitabilitas; $M O W N=$ Kepemilikan Manajerial,

DER*MOWN = Interaksi Struktur Modal dengan Kepemilikan Manajerial,

ROA*MOWN = Interaksi Profitabilitas dengan Kepemilikan Manajerial,

$\mathrm{e}=$ kesalahan residual

\section{HASIL PENELITIAN DAN PEMBAHASAN}

\section{Uji Asumsi Klasik}

Sebelum menganalisis data terlebih dahulu dilakukan uji asumsi klasik. Hasil uji asumsi klasik menunjukkan tidak semua asumsi terpenuhi. Oleh sebab itu, data pada variabel dependen dan independen ditransformasi menjadi bentuk logaritma natural (Ghozali, 2011).Setelah dilakukan transformasi data dalam bentuk logaritma natural, semua data memenuhi uji asumsi klasik Normalitas, Multikolinieritas, Heterokedastisitas, dan Autokorelasi.

\section{Analisis Regresi dan Pengujian Hipotesis}

Hasil uji yang dilakukan disajikan pada Tabel 1, Tabel 2, dan Tabel 3 dan diperoleh hasil persamaan sebagai berikut:

$$
\begin{aligned}
& \mathrm{PBV}=3.017737+0.319915 \mathrm{DER}+0.882035 \mathrm{ROA} \\
& \mathrm{PBV}=-0.512472-0.613942 \mathrm{DER}-0.150505 \mathrm{MOWN}-0.143821 \mathrm{DER}{ }^{*} \mathrm{MOWN} \\
& \mathrm{PBV}=1.209591+0.345134 \mathrm{ROA}-0.248687 \mathrm{MOWN}-0.081555 \mathrm{ROA}{ }^{*} \mathrm{MOWN}
\end{aligned}
$$


Jurnal Manajemen Bisnis, Vol 9. No 2, September 2018, E-ISSN:2622-6308 P-ISSN:2086-8200

Website: http://journal.umy.ac.id/index.php/mb

DOI:10.18196/mb.9259

Tabel 1. Hasil Analisis Regresi Linear Berganda Model 1

\begin{tabular}{ccccc}
\hline Variable & Coefficient & Std. Error & t-Statistic & Prob. \\
\hline C & 3.017737 & 0.224565 & 13.43814 & 0.0000 \\
LOG(DER) & 0.319915 & 0.072332 & 4.422881 & 0.0000 \\
LOG(ROA) & 0.882035 & 0.070028 & 12.59546 & 0.0000 \\
R-squared & 0.638800 & Mean dependent var & 0.297216 & \\
Adjusted & 0.630948 & S.D. dependent var & 1.127280 & \\
R-squared & & & & \\
\hline
\end{tabular}

Tabel 2. Hasil Uji MRA DER*MOWN Model 2

\begin{tabular}{crrrc}
\hline Variable & Coefficient & Std. Error & t-Statistic & Prob. \\
\hline C & -0.512472 & 0.232652 & -2.202743 & 0.0301 \\
LOG(DER) & -0.613942 & 0.179120 & -3.427543 & 0.0009 \\
LOG(MOWN) & -0.150505 & 0.036322 & -4.143685 & 0.0001 \\
LOG(DER)*LOG(MOWN) & -0.143821 & 0.029419 & -4.888776 & 0.0000 \\
\hline
\end{tabular}

Tabel 3. Hasil Uji MRA ROA*MOWN Model 3

\begin{tabular}{crrrc}
\hline Variable & Coefficient & \multicolumn{1}{c}{ Std. Error } & \multicolumn{1}{c}{ t-Statistic } & \multicolumn{1}{c}{ Prob. } \\
\hline C & 1.209591 & 0.400669 & 3.018928 & 0.0033 \\
LOG(ROA) & 0.345134 & 0.140694 & 2.453081 & 0.0161 \\
LOG(MOWN) & -0.248687 & 0.057411 & -4.331672 & 0.0000 \\
LOG(ROA)*LOG(MOWN) & -0.081555 & 0.021653 & -3.766445 & 0.0003 \\
\hline
\end{tabular}

\section{PEMBAHASAN}

Hasil pengujian hipotesis pertama menunjukkan bahwa nilai koefisien dari variabel DER menunjukkan nilai sebesar 0.319915. Nilai Koefisien tersebut menunjukkan bahwa struktur modal memiliki arah yang sama terhadap nilai perusahaan. DER mempunyai tingkat signifikansi sebesar 0.0000 yang menunjukkan bahwa $\mathrm{p}<0,05$ sehingga, hipotesis 1 dalam penelitian ini diterima, yang artinya struktur modal yang diukur dengan DER berpengaruh positif dan signifikan terhadap nilai perusahaan. Jadi, semakin besar struktur modal perusahaan maka semakin besar nilai perusahaannya. Hasil yang penelitian ini 
Jurnal Manajemen Bisnis, Vol 9. No 2, September 2018, E-ISSN:2622-6308 P-ISSN:2086-8200

Website: http://journal.umy.ac.id/index.php/mb

DOI:10.18196/mb.9259

sesuai dengan teori MM dengan pajak dan teori signal dimana struktur modal mempengaruhi nilai perusahaan. Perusahaan dengan hutang yang tinggi mendapatkan penghematan pajak dari bunga yang dibayarkan sehingga nilai perusahaannya tinggi. Investor juga menangkap sinyal positif bagi perusahaan yang memiliki hutang yang tinggi. Perusahaan tersebut dianggap memiliki keyakinan akan pertumbuhan perusahaan di masa yang akan datang. Penelitian ini konsisten dengan hasil penelitian Moniaga F. (2013), Pratama \& Wirawati (2016), Agnes (2013) dan Chaidir (2015) yang membuktikan bahwa struktur modal yang diukur dengan DER berpengaruh positif dan signifikan terhadap nilai perusahaan.

Hasil pengujian hipotesis kedua menunjukkan nilai koefisien ROA sebesar 0.882035 . Nilai koefisien tersebut menunjukkan bahwa profitabilitas memiliki pengaruh positif terhadap nilai perusahaan. ROA mempunyai tingkat signifikansi sebesar 0.0000 yang menunjukkan bahwa $\mathrm{p}<0,05$. Hal ini berarti hipotesis 2 dalam penelitian ini diterima. Profitabilitas yang diukur dengan ROA berpengaruh positif dan signifikan terhadap nilai perusahaan. semakin tinggi nilai profitabilitas perusahaan maka semakin tinggi nilai perusahaannya. Perusahaan yang memiliki ROA yang tinggi memberikan sinyal positif kepada investor akan prospek perusahaan di masa yang akan datang. Penelitian ini konsisten dengan penelitian yang dilakukan oleh Pratama \& Wirawati (2016), dan Ju Chen \& Yu Chen, (201) menjelaskan bahwa profitabilitas berpengaruh positif dan signifikan terhadap nilai perusahaan.

Hasil pengujian hipotesis ketiga menunjukkan hasil uji interaksi antara struktur modal dengan kepemilikan manajerial memiliki tingkat signifikansi sebesar 0.0000 ( $\mathrm{p}<$ $0,05)$, tetapi memiliki pengaruh negatif berdasarkan nilai koefisiennya $=-0.143821$. Hasil ini menunjukkan bahwa perusahaan yang menggunakan utang yang besar dalam struktur modal dengan didukung adanya kepemilikan manajerial pada perusahaan akan menurunkan nilai perusahaan tersebut. Arah negatif menunjukkan bahwa investor merasa khawatir dan menganggap bahwa peningkatan hutang ini meningkatkan resiko dan hanya tindakan manajemen yang tidak sesuai dengan kepentingan pemegang saham. Hal ini juga dijelaskan Hamidah, Ahmad \& Aulia (2015), ketika manajerial selaku pemegang saham harus berusaha meningkatkan nilai pemegang saham terdapat kemungkinan dimana manajerial memiliki tujuan pribadi yang akan bersaing dengan kepentingan 
Jurnal Manajemen Bisnis, Vol 9. No 2, September 2018, E-ISSN:2622-6308 P-ISSN:2086-8200

Website: http://journal.umy.ac.id/index.php/mb

DOI:10.18196/mb.9259

memaksimalkan nilai pemegang saham dan akan terjadi pengaruh negatif walaupun dengan adanya kepemilikan manajerial.

Hasil pengujian hipotesis keempat menunjukkan hasil uji interaksi antara variabel profitabilitas dengan kepemilikan manajerial sebesar 0.0003 dan variabel pemoderasi memiliki arah negatif dilihat dari nilai koefisiennya $=-0.081555$. Variabel kepemilikan manajerial dapat memoderasi hubungan antara profitabilitas terhadap nilai perusahaan dengan arah negatif. Pengaruh negatif ini menunjukkan adanya kekhawatiran investor dengan tindakan manajemen yang opportunistic yang cenderung mengambil keputusan untuk kepentingannya sendiri. Hasil penelitian ini mendukung penelitian Chun \& Lee (2017) yang menyatakan kepemilikan oleh pihak dalam perusahaan (manajemen) dalam jumlah yang besar akan berefek pada tindakan dan dorongan yang didapatkan manajemen perusahaan untuk bertindak sesuai kepentingan sendiri untuk mengambil risiko yang lebih ketika ada pertumbuhan peluang yang lebih baik.

\section{SIMPULAN DAN SARAN}

\section{Simpulan}

Berdasarkan hasil analisis yang telah dilakukan dapat diambil kesimpulan: (1) Struktur modal berpengaruh positif dan signifikan terhadap nilai perusahaan, (2) Profitabilitas berpengaruh positif dan signifikan terhadap nilai perusahaan, (3) Kepemilikan manajerial memoderasi pengaruh struktur modal terhadap nilai perusahaan (4) Profitabilitas yang di moderasi kepemilikan manajerial berpengaruh negatif dan signifikan terhadap nilai perusahaan.

\section{Saran}

Saran dalam penelitian ini, yaitu: (1) Bagi perusahaan yang memiliki prospek yang baik hendaknya menggunakan hutang dalam menambahkan modal karena hal itu bisa menjadi sinyal positif dan mempengaruhi nilai perusahaan, (2) Bagi investor dan calon investor perlu memperhatikan struktur modal, profitabilitas serta kepemilikan manajerial karena variabel tersebut berpengaruh terhadap kemakmuran pemegang saham, (3) Menambahkan atau memperbanyak variabel serta waktu pengamatan untuk peneliti selanjutnya. 
Jurnal Manajemen Bisnis, Vol 9. No 2, September 2018, E-ISSN:2622-6308 P-ISSN:2086-8200

Website: http://journal.umy.ac.id/index.php/mb

DOI:10.18196/mb.9259

\section{Keterbatasan Penelitian}

Keterbatasan dalam penelitian ini adalah: (1) Alat ukur atau proxy tunggal untuk setiap variabel yang diuji, (2) Variabel yang digunakan, sampel penelitian hanya 96 perusahaan dan waktu pengamatan yang terbatas. Bagian penutup berupa simpulan, keterbatasan dan saran atau implikasi hasil penelitian.

\section{DAFTAR PUSTAKA}

Adyana Putra I, W. N. (2013). Pengaruh Kepemilikan Manajerial Terhadap Hubungan Antara Kinerja Dengan Nilai Perusahaan. E-Jurnal Akuntansi 5(3), 639-651.

Agnes. (2013). Pengaruh Kepemilikan Manajerial, Struktur Modal dan Ukuran Perusahaan Terhadap Nilai Perusahaan. Universitas Negeri Padang.

Chaidir. (2015). Pengaruh Struktur Modal, Profitabilitas, Dan Pertumbuhan Perusahaan Terhadap Nilai Perusahaan Pada Perusahaan Sub Sektor Transportasi Yang Tercatat di Bursa Efek Indonesia Periode 2012-2014. Jurnal Ilmiah Manajemen Fakultas Ekonomi Volume 1 No 2 Tahun 2015, 1-21.

Chun, S. E., \& Lee, M. H. (2017). Corporate Ownership Structure and Risk Taking Evidence From Japan. Journal of Governance and Regulation Volume 6 Issue 4, 39-52.

Darmawati, D. K., \& Rahayu, R. G. (2004). Hubungan Corporate Governance dan Kinerja Perusahaan. Simposium Nasional Akuntansi VII. Denpasar.

Dewi, A., \& Wirajaya, A. (2013). Pengaruh Struktur Modal, Profitabilitas Dan Ukuran Perusahaan Pada Nilai Perusahaan. E-Jurnal Akuntansi Universitas Udayana, Vol. 4.2, Halaman 358-372.

Ghozali, I. (2011). Aplikasi Analisis Multivariate Dengan Program IBM SPSS 19. Semarang: Badan Penerbit Universitas Diponegoro.

Hamidah, Ahmad, G., \& Aulia, R. (2015). Effect Of Intellectual Capital, Capital Structure and Managerial Ownership Toward Firm Value of Manufacturing Sector Companies Listed in Indonesia Stock Exchange (IDX) Period 2010-2014. Jurnal Riset Manajemen Sains Indonesia (JRMSI), Vol. 6, No. 2.

Hanafi, M. (2014). Manajemen Keuangan Edisi Kedua. Yogyakarta: BPFE.

Hanafi, M., \& Halim, A. (2012). Analisis Laporan Keuangan. Yogyakarta: UPP STIM YKPN.

Hermastuti, C. (2014). Pengaruh Profitabilitas, Kebijakan Dividen, Kebijakan Hutang, Keputusan Investasi dan Kepemilikan Insider Terhadap Nilai Perusahaan. Jurnal Ilmu dan Riset Akuntansi Vol 3 No 4, 1-14.

Hermuningsih, S. (2012). Pengaruh Profitabilitas, Size Terhadap Nilai Perusahaan Dengan Struktur Modal Sebagai Variabel Intervening. Jurnal Siasat Bisnis, Vol. 16, No.2 Halaman 232-242.

Hoque, J., Hossain, A., \& Hossain, K. (2014). Impact of Capital Structure Policy On Value Of The Firm A Study On Some Selected Corporate Manufacturing Firms Under Dhaka Stock Exchange. ECOFORUM, 77-84.

Husnan, S. (2008). Manajemen Keuangan Teori dan Penerapannya(Keputusan Jangka Panjang). Yogyakarta: BPFE.

Jensen, M., \& Meckling, W. (1976). Theory of The Fiirm: Managerial Behaviour, Agency Cost and Ownership Structure. Journal of Financial Economics, Vol. 3 , 305-340. 
Jurnal Manajemen Bisnis, Vol 9. No 2, September 2018, E-ISSN:2622-6308 P-ISSN:2086-8200

Website: http://journal.umy.ac.id/index.php/mb

DOI:10.18196/mb.9259

Ju Chen, \& Yu Chen. (2011). The Influence of Profitability on Firm Value With Capital Structure as The Mediator and Firm Size and Industry as Moderators. Investment Management and Financial Innovations, Vol. 8, Issue 3.

Lubis, I. L., Sinaga, B. M., \& Sasongko, H. (2017). Pengaruh Profitabilitas, Struktur Modal, Dan Likuiditas Terhadap Nilai Perusahaan. Jurnal Aplikasi Bisnis dan Manajemen, Vol. 5 No. $3,458-465$.

Modigliani, F., \& Miller, M. H. (1963). Corporates Incomes Taxes and The Cost Of Capital : a corecction. American Economic Review, 53 , 433-443.

Moniaga, F. (2013). Struktur Modal, Profitabilitas dan Struktur Biaya Terhadap Nilai Perusahaan Industri Keramik Porcelen Dan Kaca Periode 2007 - 2011. Jurnal EMBA Vol.1 No. 4, 433-422.

Munandar, B. T., \& Kusumawati, R. (2017). Pengaruh Aliran Kas Bebas dan Keputusan Pendanaan Terhadap Nilai Pemegang Saham dengan Set Kesempatan Investasi Sebagai Variabel Moderating. Jurnal Manajemen dan Bisnis Vol. 3 No.1.

Nandita, A., \& Kusumawati, R. (2018). Pengaruh Profitabilitas, Leverage, Siize Dan Kebijakan Dividen Terhadap Nilai Perusahaan. CAM JOURNAL: Change Agent For Management Journal, Vol 2. No. 2 , 188 - 199.

Pratama, I., \& Wirawati, N. (2016). Pengaruh Struktur Modal dan Profitabilitas Terhadap Nilai Perusahaan dengan Kepemilikan Manajerial sebagai Pemoderasi. E-Jurnal Akuntansi Universitas Udayana, Vol. 15, Halaman 1796-1825.

Rahayu, S., \& Andri, A. (2010). Pengaruh Kinerja Keuangan Terhadap Nilai Perusahaan Dengan Pengungkapan Corporate Social Responsibility Dan Good Corporate Governance Sebagai Variabel Pemoderasi (Studi Empiris Pada Perusahaan Manufaktur di Bursa Efek Jakarta). Universitas Diponegoro.

Riyanto, B. (2001). Dasar-dasar Pembelanjaan Perusahaan Edisi Keempat Cetakan ketujuh. Yogyakarta: BPFE.

Sartono, A. (2001). Manajemen Keuangan Teori dan Aplikasi, Edisi Keempat Cetakan Pertama. Yogyakarta: BPFE.

Sujoko, \& Soebiantoro, U. (2007). Pengaruh Faktor Kepemilikan, Leverage, Faktor Intern, dan Faktor Ekstern Terhadap Nilai Perusahaan (Studi Empiris Pada Perusahaan Manufaktur dan Non Manufaktur di Bursa Efek Jakarta. Jurnal Manajemen dan Kewirausahaan 9(1) , 41-49.

Tarjo, J. (2005). Analisa Free Cash Flow Dan Kepemilikan Manajerial Terhadap Kebijakan Utang Pada Perusahaan Publik di Indonesia. Simposium Nasional Akuntansi Vi, (pp. 278-295). 